Brief Report

\title{
Impact of COVID-19 Pandemic on Flu and COVID-19 Vaccination Intentions among University Students
}

\author{
Roberta Pastorino $^{1,+}$, Leonardo Villani ${ }^{2, *}++^{\mathbb{D}}$, Marco Mariani ${ }^{2} \mathbb{D}$, Walter Ricciardi ${ }^{1,2} \mathbb{D}$, Guendalina Graffigna ${ }^{3,4} \mathbb{D}^{\mathbb{D}}$ \\ and Stefania Boccia ${ }^{1,2}$
}

check for updates

Citation: Pastorino, R.; Villani, L.; Mariani, M.; Ricciardi, W.; Graffigna, G.; Boccia, S. Impact of COVID-19 Pandemic on Flu and COVID-19 Vaccination Intentions among University Students. Vaccines 2021, 9, 70. https://doi.org/10.3390/ vaccines 9020070

Academic Editor: Davide Gori Received: 24 December 2020 Accepted: 15 January 2021 Published: 20 January 2021

Publisher's Note: MDPI stays neutral with regard to jurisdictional claims in published maps and institutional affiliations.

Copyright: (c) 2021 by the authors. Licensee MDPI, Basel, Switzerland. This article is an open access article distributed under the terms and conditions of the Creative Commons Attribution (CC BY) license (https:// creativecommons.org/licenses/by/ $4.0 /)$.
1 Department of Woman and Child Health and Public Health-Public Health Area, Fondazione Policlinico Universitario A. Gemelli IRCCS, 00168 Rome, Italy; roberta.pastorino@policlinicogemelli.it (R.P.); walter.Ricciardi@unicatt.it (W.R.); stefania.Boccia@unicatt.it (S.B.)

2 Section of Hygiene, University Department of Life Sciences and Public Health-Università Cattolica del Sacro Cuore, 00168 Rome, Italy; marcomariani1990@hotmail.it

3 Dipartimento di Psicologia-Università Cattolica del Sacro Cuore, 20123 Milan, Italy; guendalina.graffigna@unicatt.it

4 EngageMinds HUB-Consumer, Food \& Health Engagement Research Center, Università Cattolica del Sacro Cuore, 26100 Cremona, Italy

* Correspondence: leonardovillani92@gmail.com

+ Equal contribution.

\begin{abstract}
Flu vaccination for the general population, and specifically for vulnerable subgroups, brings the potential to reduce the impact of the COVID-19 pandemic in terms of mobility, mortality, and hospitalizations. In Italy, flu vaccination is recommended to all $\geq 6$ months of age, even if it is only free of charge for specific categories. We investigated the intentions towards flu and COVID-19 vaccinations from a sample of 436 Italian university students. Results of a web-based survey show that $77.52 \%$ of them were willing to get the flu vaccine and $94.73 \%$ were willing to be vaccinated against COVID-19 when available. We identified positive predictive factors to undertake flu vaccination as being a medical student, having undertaken a previous vaccination against flu, and having a high level of concern and perceived vulnerability to the COVID-19 pandemic. Reinforced public health activities might consider engaging university students a as possible "positive influencer" towards flu and COVID-19 vaccination programs.
\end{abstract}

Keywords: COVID-19 vaccination; flu vaccination; students

\section{Introduction}

Flu vaccination represents one of the most effective strategies in order to reduce the healthcare, social, and economic impact of influenza [1]. Although influenza has a high impact in terms of mortality and morbidity in Italy, with about 7 million annual cases and an average annual mortality excess rate per 100,000 ranging from 11.6 to 41.2 [2], the vaccine coverage among older people and persons with chronic illnesses is low and very distant from the 75\% recommended by the World Health Organization [3].

Since influenza and COVID-19 share similar symptomatology, especially in the first phase of the disease, a differential diagnosis between them will require tests, hospitalizations, and quarantine of symptomatic persons before obtaining the test results that could easily saturate the healthcare system capacity [4]. For this reason, there is an urgent need to implement flu vaccination for the target population [5]. In this context, some countries, Italy included, strongly recommend flu vaccination to all those people aged $\geq 6$ months, even if it is only provided free of charge for specific risk groups of the population [6,7]. Nevertheless, over the last decades, opposition to vaccination has been amplified, and the phenomenon of vaccine hesitancy has arisen. This phenomenon is defined as a set of beliefs, attitudes, and behaviors (alone or in combination), exhibited by common people and, in some cases, also by healthcare professionals, in regard to their own or their 
children's immunizations, causing a decrease of vaccine coverage and an increased risk of preventable disease epidemics [8]. In this context, the fear of potential damages after receiving the vaccine raises concern among people possibly leading to a reduction in the vaccine uptake [9]. In addition, self-perceived risk (both of influenza and COVID-19) may impact the willingness to get vaccinated [10]. Although the attitudes towards a future vaccine to prevent COVID-19 have been already investigated in the general and young population [11,12], evidence on the impact of COVID-19 pandemic on flu vaccination intentions in the young population is lacking. A special category of the young population is made up of university students, who are usually open-minded and capable to respond faster to public health issues [11].

With our study, we aimed to investigate the intentions of Italian university students regarding flu and COVID-19 vaccinations in the period of the COVID-19 pandemic, and the potential impact of concerns and perceptions about the COVID-19 pandemic on such intentions.

\section{Methods}

We conducted a web-based survey between 8 June and 12 July 2020, in the period immediately following the lifting of the Italian lockdown [13]. We administered an anonymous questionnaire on the intranet personal web page of undergraduate students attending one of the four campuses of Università Cattolica del Sacro Cuore. The University has four campuses located in the cities of Milan (Lombardy region), Brescia (Lombardy region), Piacenza-Cremona (Lombardy and Emilia-Romagna regions), and Rome (Lazio region). Therefore, there are four campuses in three different Italian regions. The faculties involved were Medicine and Surgery (Rome), Psychology (Milan and Brescia), Economy (Rome), Economy and Law (Piacenza-Cremona), Agricultural, Food, and Environmental Sciences (Piacenza-Cremona), Banking, Financial, and Insurance Sciences (Milan), and Education Sciences (Milan). The protocol of the study was approved by the Ethics Committee of the Policlinico Universitario A. Gemelli IRCCS and by the Internal Board of the University (since the voluntary and unpaid participation of students requires informed consent). The self-administered questionnaire included 30 items across three sections. Section 1 gathered students' demographic information, such as age, gender, date of birth, faculty, year of study, and residence region. Section 2 included 7 items investigating their intention to get vaccinated against influenza and their opinions about a future COVID-19 vaccine. Section 3 investigated concerns and perceptions related to fear about an increase of COVID-19 cases, deaths, risk of getting infected, capacity to contain the spread of the virus, and their understanding of preventive measures. Eventually, we performed descriptive analyses for all variables, and survey-weighted logistic regressions to assess the influence of independent variables on each binary outcome investigated (with the results expressed as odds ratios (OR), 95\% confidence interval (CI). In order to account for underrepresented groups in the student population, poststratification has been applied for adjusting the sampling weights. We considered $p$-values below 0.05 as statistically significant. We carried out all the statistical analyses using Stata software, version 14 (StataCorp LP, College Station, TX, USA).

\section{Results}

We collected a total of 436 questionnaires with a response rate of $78 \%(436 / 559)$. The median age of the students was 23.09 years (Interquartile range [IQR] 21.32-24.74), and females accounted for $70.41 \%$ of the sample. A total of $274(62.84 \%), 88(20.18 \%)$ and 74 (16.97\%) students attend the Faculty of Medicine and Surgery (medical students, dentistry, and other healthcare profession students), Faculty of Psychology (Psychology students only), and Other (Economy, Economy and Law, Agricultural, Food, and Environmental Sciences, Banking, Financial and Insurance Sciences, and Education Sciences), respectively, with an overall higher prevalence of first-and second-year students $(39.22 \%)$.

Almost eighty percent $(77.52 \%)$ of the students $(\mathrm{N}=338)$ were willing to undertake flu vaccination within the forthcoming vaccination campaign. With regard to a previous flu 
vaccination, 228 (52.29\%) students, of whom 173 (75.88\%) attend the Faculty of Medicine and Surgery, had received it at least once in their lifetime.

Concerning the opinions about a future COVID-19 vaccine, results show that 405 $(92.89 \%)$ of students declared that they would feel more defended when the vaccine is available, and 399 (91.51\%) believed that the COVID-19 vaccine will solve the emergency. Although a minority of students $(\mathrm{N}=81,18.58 \%)$ reported being afraid about possible adverse COVID-19 vaccine reactions, the majority ( $\mathrm{N}=413,94.73 \%)$ were willing to be vaccinated against COVID-19 when available. Concerning perception and concerns about the COVID-19 pandemic, over $95 \%$ of the respondents $(\mathrm{N}=420)$ reported understanding the relevance of lockdown measures adopted in the first wave of the pandemic in Italy, in terms of pandemic containment. Two hundred ninety-four students $(67.40 \%)$ referred to fear about the increase in positive cases and 314 students $(72.02 \%)$ were concerned about the reported number of deaths. In general, 169 students $(38.80 \%)$ reported great concern about the containment of the pandemic in Italy, and around $60 \%$ of the students $(\mathrm{N}=257)$ were willing to contribute more to face the pandemic. Concerning the students' social life, $74.08 \%(323), 58.48 \%(\mathrm{~N}=255)$, and $66.06 \%(\mathrm{~N}=288)$ suffered from the impossibility of seeing friends, of seeing colleagues, and of attending the university, respectively.

In the multivariable analysis of predictors of the intention to undertake flu vaccination, medical students were more willing compared to psychology and other faculties together (adjusted (adj) OR 4.89, 95\% CI (2.70-8.85)). A previous vaccination against flu was a significant predictor for repeating the vaccination (adj OR 5.82, 95\% CI (3.27-10.37)).

The concern about the general COVID-19 pandemic (adj OR 1.13, 95\% CI (0.99-1.30)), the fear about the increase in positive cases (adj OR 1.44, 95\% CI (1.14-1.83)), and deaths (adj OR 1.35, 95\% CI (1.05-1.74)) were predictors of the willingness to be vaccinated against flu. The understanding of the preventive measures was associated with the intention to get vaccinated against flu (adj OR 1.53, 95\% CI (1.02-2.29)) as well as the willingness to contribute to efforts to control the pandemic increases, although the alpha did not reach $<0.05$ (adj OR 1.22, 95\% CI (0.98-1.53)). Concerning the social life of students, the distance to colleagues, impossibility of attending university, and impossibility of seeing friends were associated with the intention to get the flu vaccine (adj OR 1.21, 95\% CI (1.01-1.46); adj OR 1.20, 95\% CI (1.01-1.44); and adj OR 1.31, 95\% CI (1.07-1.60); respectively).

Furthermore, the willingness to undertake flu vaccination was associated with the intention to get vaccinated against COVID-19 (adj OR 9.58, 95\% CI (4.78-19.19)), without differences among the faculties. Lastly, we report an association between being already vaccinated against flu, concerns about the increase in positive cases and concerns about the increase in deaths with the intention to be vaccinated against COVID-19 (adj OR 2.06, 95\% CI (1.07-3.97), adj OR 1.58, 95\% CI (1.18-2.10), and adj OR 1.68, 95\% CI (1.24-2.66), respectively). The distributions of the selected covariates and adjusted ORs are shown in Table 1. 
Table 1. Predictors of flu and COVID-19 vaccination (adjusted OR: odds ratio; CI: 95\% confidence interval).

\begin{tabular}{|c|c|c|c|c|c|}
\hline \multicolumn{6}{|c|}{ Willingness to get vaccinated } \\
\hline \multirow[t]{2}{*}{ Variable } & \multirow[t]{3}{*}{ Category } & \multicolumn{4}{|c|}{ Flu Vaccination } \\
\hline & & Yes & No & OR $(95 \%$ CI) & $p$-value \\
\hline & & $\mathrm{N}(\%)$ & $\mathrm{N}(\%)$ & & \\
\hline Total & & $338(77.52)$ & $98(22.48)$ & & \\
\hline \multirow{2}{*}{ Gender } & Female & 231 (75.24) & $76(24.76)$ & - & \\
\hline & Male & $107(82.95)$ & $22(17.05)$ & $1.31(0.75-2.28)$ & 0.34 \\
\hline & & Median (IQR) & Median (IQR) & & \\
\hline Age & & $23.0(22-25)$ & $23.0(21-25)$ & $0.98(0.94-1.03)$ & 0.45 \\
\hline \multirow{3}{*}{ Faculty } & Other & $44(59.46)$ & $30(40.54)$ & - & - \\
\hline & Medicine & $241(87.96)$ & $33(12.04)$ & $4.89(2.70-8.85)$ & $<0.0001$ \\
\hline & Psychology & $53(60.23)$ & $35(39.77)$ & $0.99(0.53-1.85)$ & \\
\hline \multirow[t]{2}{*}{ Campus } & $\begin{array}{c}\text { (Brescia, Milano, } \\
\text { Piacenza-Cremona) }\end{array}$ & $92(58.97)$ & $64(41.03)$ & - & \\
\hline & Rome & $246(87.86)$ & $34(12.14)$ & $4.95(3.05-8.06)$ & $<0.0001$ \\
\hline \multirow{5}{*}{$\begin{array}{l}\text { Understand preventive } \\
\text { measures }\end{array}$} & Strongly disagree & 0 & 0 & - & \\
\hline & Disagree & $1(50.00)$ & $1(50.00)$ & $1.53(1.02-2.29)$ & 0.038 \\
\hline & Moderate & $7(50.00)$ & $7(50.00)$ & & \\
\hline & Agree & $102(79.07)$ & $27(20.93)$ & & \\
\hline & Strongly agree & $228(78.35)$ & $63(21.65)$ & & \\
\hline Concern about the & No & $90(67.67)$ & $43(32.33)$ & - & \\
\hline COVID-19 pandemic & Yes & $243(81.81)$ & $54(18.19)$ & $1.13(0.99-1.30)$ & 0.069 \\
\hline \multirow{5}{*}{$\begin{array}{l}\text { Fear about the increase in } \\
\text { deaths }\end{array}$} & Strongly disagree & $4(44.44)$ & $5(55.56)$ & - & \\
\hline & Disagree & $23(65.71)$ & $12(34.29)$ & $1.35(1.05-1.74)$ & 0.019 \\
\hline & Moderate & $61(78.21)$ & $17(21.79)$ & & \\
\hline & Agree & $120(80.00)$ & $30(20.00)$ & & \\
\hline & Strongly agree & $130(79.27)$ & $34(20.73)$ & & \\
\hline \multirow{5}{*}{$\begin{array}{l}\text { Fear about the increase in } \\
\text { positive cases }\end{array}$} & Strongly disagree & $5(41.67)$ & $7(58.33)$ & - & \\
\hline & Disagree & $28(68.29)$ & $13(31.71)$ & $1.44(1.14-1.83)$ & 0.003 \\
\hline & Moderate & $67(75.28)$ & $22(24.72)$ & & \\
\hline & Agree & $130(81.76)$ & $29(18.24)$ & & \\
\hline & Strongly agree & $108(80.00)$ & $27(20.00)$ & & \\
\hline \multirow{5}{*}{$\begin{array}{l}\text { Suffering from distance to } \\
\text { fellow students }\end{array}$} & Strongly disagree & $37(75.51)$ & $12(24.49)$ & - & \\
\hline & Disagree & $39(70.91)$ & $16(29.09)$ & $1.21(1.01-1.46)$ & 0.035 \\
\hline & Moderate & $53(68.83)$ & $24(31.17)$ & & \\
\hline & Agree & $117(79.05)$ & $31(20.95)$ & & \\
\hline & Strongly agree & $92(85.95)$ & $15(14.02)$ & & \\
\hline \multirow{5}{*}{$\begin{array}{l}\text { Suffering from the } \\
\text { impossibility of attending } \\
\text { university }\end{array}$} & Strongly disagree & 35 (79.55) & $9(20.45)$ & - & \\
\hline & Disagree & $31(64.58)$ & $17(35.42)$ & $1.20(1.01-1.44)$ & 0.042 \\
\hline & Moderate & $40(71.43)$ & $16(28.57)$ & & \\
\hline & Agree & $117(78.52)$ & $32(21.48)$ & & \\
\hline & Strongly agree & $115(82.73)$ & $24(17.27)$ & & \\
\hline \multirow{5}{*}{$\begin{array}{l}\text { Suffering from distance to } \\
\text { friends }\end{array}$} & Strongly disagree & $11(68.75)$ & $5(31.25)$ & - & \\
\hline & Disagree & $16(50.00)$ & $16(50.00)$ & $1.31(1.07-1.60)$ & 0.009 \\
\hline & Moderate & 49 (75.38) & $16(24.62)$ & & \\
\hline & Agree & $101(81.45)$ & $23(18.55)$ & & \\
\hline & Strongly agree & $161(80.90)$ & 38 (19.10) & & \\
\hline \multirow{5}{*}{$\begin{array}{l}\text { Desire to contribute much } \\
\text { more to facing the } \\
\text { pandemic }\end{array}$} & Strongly disagree & $10(61.50)$ & $6(37.50)$ & - & \\
\hline & Disagree & $31(70.45)$ & $13(29.55)$ & $1.22(0.98-1.53)$ & 0.081 \\
\hline & Moderate & $84(70.59)$ & $35(29.41)$ & & \\
\hline & Agree & $124(82.12)$ & $27(17.88)$ & & \\
\hline & Strongly agree & 89 (83.96) & $17(16.04)$ & & \\
\hline \multirow{2}{*}{ Previous flu vaccination } & No & $128(61.54)$ & $80(38.46)$ & - & \\
\hline & Yes & $210(92.11)$ & $18(7.89)$ & $5.82(3.27-10.37)$ & $<0.0001$ \\
\hline \multirow{2}{*}{$\begin{array}{l}\text { COVID-19 vaccine } \\
\text { intention }\end{array}$} & No & $16(32.00)$ & $34(68.00)$ & - & \\
\hline & Yes & $322(83.42)$ & $64(16.58)$ & $9.58(4.78-19.19)$ & $<0.0001$ \\
\hline
\end{tabular}


Table 1. Cont.

\begin{tabular}{|c|c|c|c|c|c|}
\hline \multicolumn{6}{|c|}{ Willingness to get vaccinated } \\
\hline \multirow[t]{3}{*}{ Variable } & \multirow[t]{3}{*}{ Category } & \multicolumn{4}{|c|}{ COVID-19 vaccination } \\
\hline & & Yes & No & OR $(95 \%$ CI $)$ & $p$-value \\
\hline & & $\mathrm{N}(\%)$ & $\mathrm{N}(\%)$ & & \\
\hline Total & & $386(88.53)$ & 50 (11.47) & & \\
\hline \multirow{2}{*}{ Gender } & Female & $266(86.64)$ & $41(13.36)$ & - & \\
\hline & Male & $120(93.02)$ & $9(6.98)$ & $1.82(0.85-3.92)$ & 0.12 \\
\hline \multirow{3}{*}{ Age } & & Median (IQR) & Median (IQR) & & \\
\hline & & $23.0(22-25)$ & $23.0(21-25)$ & $0.99(0.94-1.05)$ & 0.657 \\
\hline & Other & $66(89.19)$ & $8(10.81)$ & - & - \\
\hline \multirow[t]{2}{*}{ Faculty } & Medicine & $254(92.70)$ & $20(7.30)$ & $1.57(0.66-3.76)$ & 0.306 \\
\hline & Psychology & $66(75.00)$ & $22(25.00)$ & $0.38(0.15-1.01)$ & 0.051 \\
\hline Campus & $\begin{array}{c}\text { (Brescia, Milano, } \\
\text { Piacenza-Cremona) }\end{array}$ & $128(82.05)$ & $28(17.95)$ & - & \\
\hline \multirow{6}{*}{$\begin{array}{l}\text { Understand preventive } \\
\text { measures }\end{array}$} & Rome & $258(92.14)$ & $22(7.86)$ & $2.48(1.34-4.57)$ & 0.004 \\
\hline & Strongly disagree & $0(00.00)$ & $0(00.00)$ & - & \\
\hline & Disagree & $1(50.00)$ & $1(50.00)$ & $1.66(0.97-2.83)$ & 0.064 \\
\hline & Moderate & $8(57.14)$ & $6(42.86)$ & & \\
\hline & Agree & $119(92.25)$ & $10(7.75)$ & & \\
\hline & Strongly agree & $258(88.66)$ & 33 (11.34) & & \\
\hline \multirow{2}{*}{$\begin{array}{l}\text { Concern about the } \\
\text { COVID-19 pandemic }\end{array}$} & No & $29(58.00)$ & $21(42.00)$ & - & \\
\hline & Yes & $268(70.53)$ & $112(29.47)$ & $1.18(0.99-1.40)$ & 0.068 \\
\hline \multirow{5}{*}{$\begin{array}{l}\text { Fear about the increase } \\
\text { in deaths }\end{array}$} & Strongly disagree & $4(44.44)$ & $5(55.56)$ & - & \\
\hline & Disagree & $29(82.86)$ & $6(17.14)$ & $1.68(1.24-2.66)$ & 0.001 \\
\hline & Moderate & $66(84.62)$ & $12(15.38)$ & & \\
\hline & Agree & $138(92.00)$ & $12(8.00)$ & & \\
\hline & Strongly agree & $149(90.85)$ & $15(9.15)$ & & \\
\hline \multirow{5}{*}{$\begin{array}{l}\text { Fear about the increase } \\
\text { in positive cases }\end{array}$} & Strongly disagree & $6(05.00)$ & $6(50.00)$ & - & \\
\hline & Disagree & $36(87.80)$ & $5(12.20)$ & $1.58(1.18-2.10)$ & 0.002 \\
\hline & Moderate & $75(84.27)$ & $14(15.73)$ & & \\
\hline & Agree & 147 (92.45) & $12(7.53)$ & & \\
\hline & Strongly agree & $122(90.37)$ & $13(9.63)$ & & \\
\hline \multirow{5}{*}{$\begin{array}{l}\text { Suffering from distance } \\
\text { to fellow students }\end{array}$} & Strongly disagree & $41(83.67)$ & $8(16.33)$ & - & \\
\hline & Disagree & $44(80.00)$ & $11(20.00)$ & $1.23(0.97-1.55)$ & 0.084 \\
\hline & Moderate & $66(89.61)$ & $8(10.39)$ & & \\
\hline & Agree & $136(91.89)$ & $12(8.11)$ & & \\
\hline & Strongly agree & $96(89.72)$ & $11(10.28)$ & & \\
\hline \multirow{5}{*}{$\begin{array}{l}\text { Suffering from the } \\
\text { impossibility of } \\
\text { attending university }\end{array}$} & Strongly disagree & $39(88.64)$ & $5(11.36)$ & - & \\
\hline & Disagree & $39(81.25)$ & $9(18.75)$ & $1.06(0.84-1.35)$ & 0.6 \\
\hline & Moderate & $52(92.86)$ & $4(7.14)$ & & \\
\hline & Agree & $133(89.26)$ & $16(10.74)$ & & \\
\hline & Strongly agree & $123(88.49)$ & $16(11.51)$ & & \\
\hline \multirow{5}{*}{$\begin{array}{l}\text { Suffering from distance } \\
\text { to friends }\end{array}$} & Strongly disagree & $10(62.50)$ & $6(37.50)$ & - & \\
\hline & Disagree & $29(90.63)$ & $3(9.38)$ & $1.30(1.01-1.67)$ & 0.045 \\
\hline & Moderate & $56(86.15)$ & $9(13.85)$ & & \\
\hline & Agree & $110(88.71)$ & $14(11.29)$ & & \\
\hline & Strongly agree & 181 (90.95) & $18(9.05)$ & & \\
\hline \multirow{5}{*}{$\begin{array}{l}\text { Desire to contribute } \\
\text { much more to facing the } \\
\text { pandemic }\end{array}$} & Strongly disagree & $11(68.75)$ & $5(31.25)$ & - & \\
\hline & Disagree & $39(88.64)$ & $5(11.36)$ & $1.24(0.91-1.68)$ & 0.178 \\
\hline & Moderate & $104(87.39)$ & $15(12.61)$ & & \\
\hline & Agree & $136(90.07)$ & $15(9.93)$ & & \\
\hline & Strongly agree & $96(90.57)$ & $10(9.43)$ & & \\
\hline \multirow{2}{*}{ Previous flu vaccination } & No & $174(83.65)$ & $34(16.35)$ & - & \\
\hline & Yes & $212(92.98)$ & $16(7.02)$ & $2.06(1.07-3.97)$ & 0.032 \\
\hline
\end{tabular}




\section{Discussion}

In 2019, the WHO listed vaccine hesitancy as one of the 10 top health threats of that year [14]. In 2020, in the midst of the COVID-19 pandemic, vaccine hesitancy appears as an even more challenging health threat as it can compromise the effectiveness of any new potential vaccine $[15,16]$ at the population level. In the past seasonal campaigns, in Italy, flu vaccine coverage lagged far from the values of at least $75 \%$ [17] as a minimum target and even farther from the $95 \%$ optimal target. In fact, after a peak in the 2005/06 season when $68.3 \%$ of the elderly population got vaccinated against influenza, a steady decline was reported, reaching $54.6 \%$ in the past $2019 / 20$ season $[18,19]$. The flu vaccination coverage is even lower in the general population, reaching a 16.8\% coverage rate in $2019 / 20$ (3.1\% in the age class 18-44 years) [19]. In our study, we investigated the intentions towards flu and COVID-19 vaccinations in a sample of university students, in Italy, that attend different faculties including Medicine and Surgery. The results show that the vast majority of the students are willing to undertake flu vaccination during the COVID-19 pandemic period. Therefore, despite the fact that, in general, students are a population that presents a low flu vaccination intention, the pandemic may have increased the willingness to vaccinate. It has already been observed, in fact, that an intention to vaccinate has reached almost $60 \%$ in the student population for the 2020-21 campaign [20], a figure higher than the average values generally observed at the national level. Our study shows a slightly higher willingness to vaccinate $(77 \%)$ which could be explained by the greater presence of medical students in our sample, who are more willing to vaccinate. In this context, the risk perception may increase the willingness to get vaccinated, especially in medical students, as a higher self-perceived risk of contracting influenza is associated with better adherence to flu vaccination [10].

An even greater proportion of students would undertake COVID-19 vaccination once becomes available. In particular, as to flu vaccination, we found that being a Medicine and Surgery student and having undertaken a previous flu vaccination significantly predicts the intention of being vaccinated against influenza. Similarly, general concerns about the pandemic, increase of positive cases, increase in the number of deaths, as well as the distance to maintain with colleagues, the impossibility of attending university, and the impossibility of seeing friends were significantly associated with the intention to be vaccinated against flu. In parallel, those who declared to be more willing to undertake flu vaccination would also be significantly more willing to get vaccinated against COVID-19.

Recently a multicentric survey, conducted across 6 countries addressed to caregivers of children and adolescents aged from 1 to 19 years of age, reported an increase of $15.9 \%$ in the intentions to vaccinate children with respect to the previous year [21]. As to the COVID-19 vaccine, a multicentric survey conducted in July 2020 on 13,426 subjects from 19 countries, reported that $71.5 \%$ of respondents were very or somewhat likely to get vaccinated against COVID-19 [22] while considering a sample of 968 Italian citizens, 59\% of the respondents reported to be likely to vaccinate for COVID-19 [16].

Overall, young adults, although less likely experience severe symptoms or death [23], are infectious if they acquire the SARS-CoV-2, and since they are internationally recognized as a group with potentially low compliance with public health measures, because of gatherings, and they maintain large and active social lives [24-26], they can play an important part in the spread of the virus in the community $[27,28]$.

However, accumulating evidence shows that the level of concern and perceived vulnerability as occurring during the COVID-19 pandemic are a motivating factor to undertake a vaccine and, in particular, the flu vaccine [20]. In fact, the perceived level of a health threat is a strong predictor of people's intention to adopt preventive behaviors, including undertaking flu vaccination [29-31]. On the other hand, however, emotional distress levels linked to health threats are voluble and changing over time and cannot guarantee that intentions to behave in a preventive manner will concretely translate into a concrete enactment of preventive behaviors. This implies that future educational flu vaccination campaigns should particularly rely on increasing individual literacy about the flu vaccine, reassuring on vaccine effectiveness and safety as well as sustaining a cultural 
change towards an engaged and aware approach to self-health management in order to guarantee adequate levels of population immunization against the risk of infectious diseases [32]. Furthermore, sensitizing campaigns to increase vaccination uptake should also focus on the social consequences of not getting vaccinated, since the role of pro-social messages in public health communication was widely demonstrated as a persuasive means for delivering preventive messages, particularly during the COVID-19 pandemic [33].

In interpreting the results of our survey, we acknowledge its main limitations: sampling was opportunistic so that we cannot infer the results to the entire Italian university student population; results might overestimate the willingness to undertake flu vaccination as medical students are a highly recommended target by the national immunization plan; lastly, we missed information from non-respondents.

Nonetheless, to our knowledge, this is the first study that investigates the impact of the COVID-19 pandemic on flu and COVID-19 vaccination intentions among university students and the possible influencing factors. Results show that university students represent a highly motivated population to undertake influenza vaccination and, even more so, the COVID-19 vaccination when made available. This trend needs to be better assessed over time as it could result from momentary concerns and vulnerability of the responders. For this reason, public health activities should keep their focus on cultural actions for students of all grades at multiple times, as engaging them at an earlier life stage can benefit themselves and, consequently, the whole society.

\section{Conclusions}

Flu vaccination represents, especially during the COVID-19 pandemic, a key tool to reduce mortality, morbidity and hospitalizations due to influenza. In particular, the involvement of the entire population could significantly contribute to reduce the spread of the influenza virus during the pandemic period. In this context, it is important to consider people and students' willingness and intent to get vaccinated. Among these latter, being a medical student, having undertaken a previous vaccination against flu and having a high level of concern and perceived vulnerability to the COVID-19 pandemic positively predicts the intention to undertake flu vaccination. Moreover, understanding vaccination intentions for COVID-19 among students is also important as it helps to ensure adequate levels of population immunization against COVID-19. Indeed, students have an active social live based on relationships and, in this context, their vaccination uptake could play an important role in fighting the spread of the virus in the community. In this context, our study highlights that students are strongly involved and are willing to undertake both vaccinations.

Author Contributions: All authors contributed to the study conception and design. Material preparation and data collection were performed by L.V., R.P., M.M., G.G., and S.B., R.P. and L.V. performed the statistical analysis. The first draft of the manuscript was written by L.V., R.P., M.M., G.G., S.B. commented on the latest version of the manuscript. W.R., G.G., and S.B. supervised the study. All authors have read and agreed to the published version of the manuscript.

Funding: This research received no external funding.

Institutional Review Board Statement: The study was approved by the Ethics Committee (Prot. ID 3242) of the Policlinico Universitario A. Gemelli IRCCS and by the Internal Board of Università Cattolica del Sacro Cuore.

Informed Consent Statement: Informed consent was obtained from all subjects involved in the study.

Data Availability Statement: Data presented in this study are available upon request from the corresponding author. Data are not publicly available as they are property of the Università Cattolica del Sacro Cuore, Rome Italy.

Conflicts of Interest: The authors declare no conflict of interest. 


\section{References}

1. Cassini, A.; Colzani, E.; Pini, A.; Mangen, M.J.J.; Plass, D.; McDonald, S.A.; Maringhini, G.; van Lier, A.; Haagsma, J.A.; Havelaar, A.H.; et al. Impact of infectious diseases on population health using incidence-based disability-adjusted life years (DALYs): Results from the burden of communicable diseases in Europe study, European Union and European economic countries, 2009 to 2013. Eurosurveillance 2018, 23, 1-20. [CrossRef]

2. Rosano, A.; Bella, A.; Gesualdo, F.; Acampora, A.; Pezzotti, P.; Marchetti, S.; Ricciardi, W.; Rizzo, C. Investigating the impact of influenza on excess mortality in all ages in Italy during recent seasons (2013/14-2016/17 seasons). Int. J. Infect. Dis. 2019, 88, 127-134. [CrossRef] [PubMed]

3. World Health Organization. Evaluation of Seasonal Influenza Vaccination Policies and Coverage in the Results from the 2008/2009 and 2009/2010. 2010. Available online: https://www.euro.who.int/_data/assets/pdf_file/0003/241644/Evaluationof-seasonal-influenza-vaccination-policies-and-coverage-in-the-WHO-European-Region.pdf (accessed on 22 December 2020).

4. Boccia, S.; Ricciardi, W.; Ioannidis, J.P.A. What Other Countries Can Learn from Italy During the COVID-19 Pandemic. JAMA Intern. Med. 2020, 180, 927-928. [CrossRef]

5. Jaklevic, M.C. Flu Vaccination Urged During COVID-19 Pandemic. JAMA 2020, 324. [CrossRef]

6. Centers for Disease Control and Prevention. Who Needs a Flu Vaccine and When. 2020. Available online: https://www.cdc.gov / $\mathrm{flu} /$ prevent/vaccinations.htm (accessed on 22 December 2020).

7. Ministero della Salute. Prevenzione e Controllo Influenza: Raccomandazioni per la Stagione 2020-2021. Ultimo Accesso 2020, $1,1-27$.

8. Dubé, E.; Laberge, C.; Guay, M.; Bramadat, P.; Roy, R.; Bettinger, J. Vaccine hesitancy: An over-view. Hum. Vaccines Immunother 2013, 9, 1763-1773. [CrossRef]

9. Di Pietro, M.L.; Poscia, A.; Teleman, A.A.; Maged, D.; Ricciardi, W. Vaccine hesitancy: Parental, professional and public responsibility. Ann. Ist. Super. Sanità 2017, 53, 157-162. [PubMed]

10. Costantino, C.; Ledda, C.; Squeri, R.; Restivo, V.; Casuccio, A.; Rapisarda, V.; Graziano, G.; Alba, D.; Cimino, L.; Conforto, A.; et al. Attitudes and perception of healthcare workers concerning influenza vaccination during the 2019/2020 season: A survey of sicilian university hospitals. Vaccines 2020, 8, 686. [CrossRef] [PubMed]

11. Harrison, E.A.; Wu, J.W. Vaccine confidence in the time of COVID-19. Eur. J. Epidemiol. 2020, 35, 325-330. [CrossRef] [PubMed]

12. Barello, S.; Nania, T.; Dellafiore, F.; Graffigna, G.; Caruso, R. 'Vaccine hesitancy' among university students in Italy during the COVID-19 pandemic. Eur. J. Epidemiol. 2020, 35, 781-783. [CrossRef]

13. Boccia, S.; Cascini, F.; McKee, M.; Ricciardi, W. How the Italian NHS Is Fighting Against the COVID-19 Emergency. Front. Public Health 2020, 8, 1-3. [CrossRef] [PubMed]

14. World Health Organization. Ten Threats to Global Health in 2019. 2019. Available online: https://www.who.int/news-room/ spotlight/ten-threats-to-global-health-in-2019 (accessed on 22 December 2020).

15. Graffigna, G.; Palamenghi, L.; Barello, S.; Stefania, B. Cultivating acceptance of a COVID-19 vaccination program: Lessons from Italy. Vaccine 2020, 38, 7585-7586. [CrossRef] [PubMed]

16. Palamenghi, L.; Barello, S.; Boccia, S.; Graffigna, G. Mistrust in biomedical research and vaccine hesitancy: The forefront challenge in the battle against COVID-19 in Italy. Eur. J. Epidemiol. 2020, 35, 785-788. [CrossRef] [PubMed]

17. Ministero della Salute. Piano Nazionale Prevenzione Vaccinale PNPV 2017-2019. 2017. Available online: http://www. quotidianosanita.it/allegati/allegato1955037.pdf (accessed on 22 December 2020).

18. Manzoli, L.; Gabutti, G.; Siliquini, R.; Flacco, M.E.; Villari, P.; Ricciardi, W. Association between vaccination coverage decline and influenza incidence rise among Italian elderly. Eur. J. Public Health 2018, 28, 740-742. [CrossRef]

19. Ministero Della Salute. Dati Coperture Vaccinali. 2020. Available online: http://www.salute.gov.it/portale/influenza/ dettaglioContenutiInfluenza.jsp?lingua=italiano\&id=679\&area=influenza\&menu=vuoto (accessed on 13 July 2020).

20. Domnich, A.; Cambiaggi, M.; Vasco, A.; Maraniello, L.; Ansaldi, F.; Baldo, V.; Bonanni, P.; Calabrò, G.E.; Costantino, C.; de Waure, C.; et al. Attitudes and beliefs on influenza vaccination during the covid-19 pandemic: Results from a representative italian survey. Vaccines 2020, 8, 711. [CrossRef]

21. Goldman, R.D.; McGregor, S.; Marneni, S.R.; Katsuta, T.; Griffiths, M.A.; Hall, J.E.; Seiler, M.; Klein, E.J.; Cotanda, C.P.; Gelernter, R.; et al. Willingness to Vaccinate Children against Influenza after the Coronavirus Disease 2019 Pandemic. J. Pediatr. 2020. [CrossRef]

22. Lazarus, J.V.; Ratzan, S.C.; Palayew, A.; Gostin, L.O.; Larson, H.J.; Rabin, K.; Kimball, S.; El-Mohandes, A. A global survey of potential acceptance of a COVID-19 vaccine. Nat. Med. 2020, 1-4. [CrossRef]

23. Pan, A.; Liu, L.; Wang, C.; Guo, H.; Hao, X.; Wang, Q.; Huang, J.; He, N.; Yu, H.; Lin, X.; et al. Association of Public Health Interven-tions with the Epidemiology of the COVID-19 Outbreak in Wuhan, China. JAMA J. Am. Med. Assoc. 2020, 323, 1915-1923. [CrossRef]

24. Park, C.; Russell, B.S.; Fendrich, M.; Finkelstein-Fox, L.; Hutchison, M.; Becker, J. Americans' COVID-19 Stress, Coping, and Adherence to CDC Guidelines. J. Gen. Intern. Med. 2020, 35, 2296-2303. [CrossRef]

25. Barari, S.; Caria, S.; Davola, A.; Falco, P.; Fetzer, T.; Fiorin, S.; Hensel, L.; Ivchenko, A.; Jachimowicz, J.; King, G.; et al. Evaluating COVID-19 public health messaging in Italy: Self-reported compliance and growing mental health concerns. medRxiv 2020, 1-19. 
26. Nivette, A.; Ribeaud, D.; Murray, A.; Steinhoff, A.; Bechtiger, L.; Hepp, U.; Shanahan, L.; Eisner, M. Non-compliance with COVID-19-related public health measures among young adults in Switzerland: Insights from a longitudinal cohort study. Soc. Sci. Med. 2021, 268, 113370. [CrossRef] [PubMed]

27. Andrews, J.L.; Foulkes, L.; Blakemore, S.-J. Peer Influence in Adolescence: Public-Health Implications for COVID-19. Trends Cogn. Sci. 2020, 24, 585-587. [CrossRef] [PubMed]

28. Cohen, A.K.; Hoyt, L.T.; Dull, B. A Descriptive Study of COVID-19-Related Experiences and Perspectives of a National Sample of College Students in Spring 2020. J. Adolesc. Health 2020, 67, 369-375. [CrossRef] [PubMed]

29. Ng, T.W.; Cowling, B.J.; So, H.C.; Ip, D.K.; Liao, Q. Testing an integrative theory of health behavioural change for predicting seasonal influenza vaccination uptake among healthcare workers. Vaccine 2019, 38, 690-698. [CrossRef]

30. Iannone, P.; Bosio, A.C.; Ricciardi, W. Recommendations for Promoting Patient Engagement in Chronic Care: A Consensus Conference Statement Recommendations for Promoting Patient Engagement in Chronic Care: A Consensus Conference Statement. Preprints 2020, 2020020016. [CrossRef]

31. Graffigna, G.; Palamenghi, L.; Boccia, S.; Barello, S. Relationship between Citizens' Health Engagement and Intention to Take the COVID-19 Vaccine in Italy: A Mediation Analysis. Vaccines 2020, 8, 576. [CrossRef]

32. Piltch-Loeb, R.; Diclemente, R. The vaccine uptake continuum: Applying social science theory to shift vaccine hesitancy. Vaccines 2020, 8, 76. [CrossRef]

33. Bellato, A. Psychological factors underlying adherence to COVID-19 regulations: A commentary on how to promote compliance through mass media and limit the risk of a second wave. Soc. Sci. Humanit. Open 2020, 2, 100062. [CrossRef] 